\title{
A SIMILARITY CRITERION FOR SPHERICAL FUEL ELEMENTS FREE FALL VELOCITY IN CYLINDRICAL CHANNELS WITH VISCOUSE LIQUID
}

\author{
Oksana L. Andrieieva ${ }^{1,2}$, Leonid A. Bulavin ${ }^{3}$, Victor I. Tkachenko ${ }^{1,2}$ \\ ${ }^{1}$ National Science Center "Kharkov Institute of Physics and Technology”, Kharkiv, Ukraine; \\ ${ }^{2}$ V.N. Karazin Kharkiv National University, Kharkiv, Ukraine; \\ ${ }^{3}$ Taras Shevchenko National University of Kyiv, Kyiv, Ukraine \\ E-mail: andreevaoksana@kipt.kharkov.ua, tel. +380(097)292-06-15
}

The introduction of nuclear high-temperature gas-cooled reactors (HTGR) with an active zone based on spherical fuel elements (SFE) poses the task of determining the velocity of their free fall in cylindrical channels with a viscous liquid. To solve it, the experimental data of other researchers are generalized, and for a certain range of Reynolds numbers the criterion of similarity for the velocity of free fall of spheres in cylindrical channels with water is found. The criterion is formulated on the basis of the Freud number. It is shown that from the dependence of the velocity of falling of the model sphere in a cylindrical vessel with water on the dimensionless diameter of the sphere, it is possible to determine the velocity of falling of the sphere in water, arbitrary.

PACS: 47.10. ab; 28.41.Te; 28.50.-k; 28.90.+i

The world is currently conducting active research on the transition of nuclear energy to more efficient hightemperature gas-cooled reactors (HTGR) [1-3]. HTGR may have an core based on spherical fuel elements (SFE), usually with a diameter of $60 \mathrm{~mm}$ [4]. Under the action of the helium gas cooler, the QDs move in cylindrical channels of the graphite masonry of the reactor with diameters of $70.7 \mathrm{~mm} \mathrm{[5],} \mathrm{or} 75 \mathrm{~mm} \mathrm{[6].}$

At the early stages of HTGR development, both bulk-type and channel-type core structures were considered. For example, the HTR-500 is a channel-type reactor. This concept of HTGR reactors remains relevant for the current level of development of hightemperature reactor technology.

Helium is at a high temperature $\left(\sim 950{ }^{\circ} \mathrm{C}\right)$. Therefore, to ensure the efficiency of HTGR there is a problem of determining the parameters of the motion of the SFE in the gas-filled cylindrical channels. To simplify the solution of the problem, instead of gas, you can consider a liquid. This replacement of gas by liquid is based on the fact that the parameters of the motion of spheres in gaseous media are similar to their motion in Newtonian fluids, because they are described by the Navier-Stokes equation and similarity criteria [7]. Thus, to determine the efficiency of HTGR, it is necessary to be able to reliably measure the velocity of free (under the action of gravity) SFE in the cylindrical channels.

However, reliable measurement of the velocity of balls falling in the axial direction in cylindrical channels is an urgent task in other areas of practice. For example, in medicine, reliable measurement of the velocity of spheres is necessary to describe the sedimentation of spherical particles in viscous liquids [8], in viscometry to assess the error in determining the velocity of the ball through shielding the walls of the channel [9]. The existing literature on the influence of the walls and the height of the channel at the time of publication of the article [9] is quite detailed (see bibliography [9]). Most of these studies relate to the area of laminar flow. The results of studies in the intermediate flow region (Reynolds numbers from 1 to 500), and some results in the turbulent region (Reynolds numbers over 500) were also systematized. In general, in [9] the results of experiments with 60 spheres, which cover a wide range of diameters of spheres and channels, using four cylinders (channels) of different diameters and fifteen Newtonian fluids of different viscosity and density. The Reynolds number varied in the range from 0.054 to 20.000 . The obtained experimental results were used to assess the reliability of previously obtained formulas taking into account the shielding of the motion of the sphere by the walls of the channel. Data on the study of the velocity of free fall of a spherical particle in a cylindrical channel were used as a basis for describing the processes of deposition of suspensions that contain spherical particles [10]. In this work, using a hydrodynamic analogy between a single particle falling in a cylindrical channel and a suspension of many particles, a relation is obtained to describe the effect of walls on the final deposition velocity of an individual particle in such a channel. The ratio obtained in this paper, in contrast to existing models, is valid for any flow regime (from viscous to completely inertial), and agrees well with the experimental data.

As we can see, studies of the dependence of the velocity of free fall of spheres on the diameter of a cylindrical channel are relevant both in scientific terms and in applied applications.

For the practical application of methods for calculating the parameters of free fall of a sphere in a cylindrical channel with a viscous fluid, it is important to determine the velocity of a spherical object under the action of external forces under conditions of shielding by the channel walls.

Therefore, the goal of this work is to determine the physical laws of motion of spheres in viscous fluids in cylindrical channels of different diameters. 


\section{ANALYSIS OF EXPERIMENTAL DATA}

To determine the physical laws of motion of spheres in cylindrical channels with a viscous fluid, we consider the experimental results presented in [9]. Consider the results of a study of the dependence of the velocity of spheres in water on their diameter. In Fig. 1,a are shown graphs of the dependence of the velocity of spheres in water on their diameter. In Fig. 1,b shows the same graphs, but taking into account the condition of similarity based on the dimensionless number of Froude (NF) $[7,11]$. NF characterizes the relationship between the force of inertia and the external force in the field of which the motion occurs:

$$
F r=\frac{\mathrm{v}^{2}}{a L},
$$

where $\mathrm{v}$ - the characteristic velocity of the fluid or moving body; $a$ - acceleration, which characterizes the action of external forces; $L-$ the characteristic size of the flow or body.

For example, NF can be used when considering the flow of fluid in a pipe in the gravitational field. In this case, under the value $a$ use the acceleration of free fall $g=9.81 \mathrm{~m} / \mathrm{s}^{2}$, under the value $\mathrm{v}$ - the flow velocity or velocity of the body and as $L$ can be considered the diameter of the tube $D$.

The similarity condition is the equality of the NF for the model and for the tested objects. This condition is used, for example, when modeling the movement of ships [12], water flows in open channels, testing models of hydraulic structures, etc.

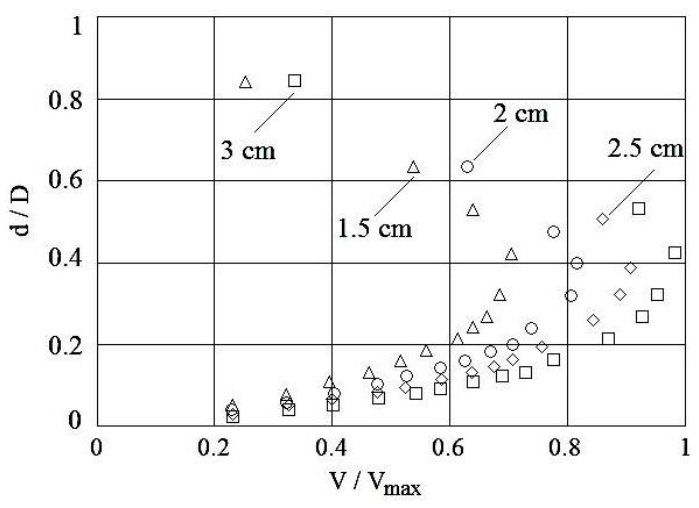

$a$

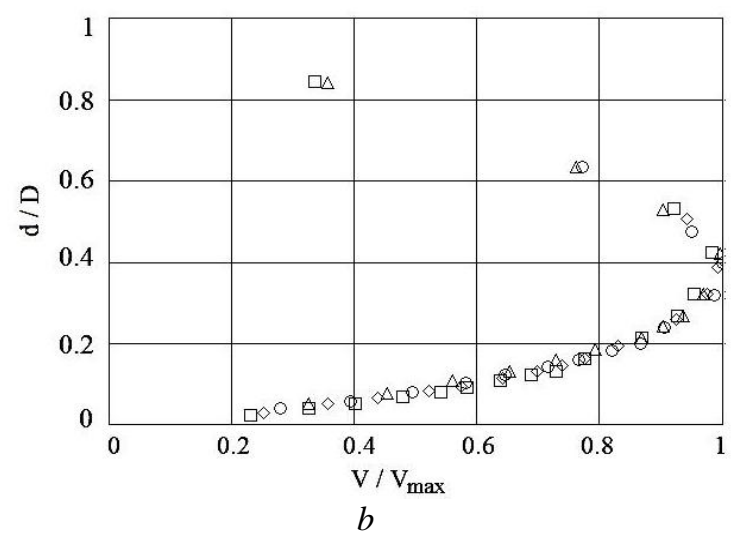

Fig. 1. The dependence of the velocity of spheres in water $v / v_{\max }$ on their diameter $d / D$. Diameter of the cylindrical channel $D=1.5 ; 2 ; 2.5 ; 3, v_{\max }=131 \mathrm{~cm} / \mathrm{s}$
Based on Fig. 1, the similarity of the velocity of movement of the spheres follows from the equality of the NF for vessels of different diameters. This can be easily Fig. 1,a verified using the expression:

$$
\mathrm{v}_{x}=\mathrm{v}_{3} \sqrt{\mathrm{D}_{x} / \mathrm{D}_{3}},
$$

where $v_{3}$ - velocity of the model sphere with a diameter $\mathrm{D}_{3}=3 \mathrm{~cm} ; \mathrm{v}_{x}, \mathrm{D}_{x}-$ velocity and diameter of the test spheres, respectively, the index $x$ takes on values $1.5 ; 2 ; 2.5 ; 3$.

From (2) it follows that the velocity of spheres with a diameter $\mathrm{d}$ in cylindrical vessels with a diameter $\mathrm{D}=1.5 ; 2 ; 2.5 ; 3 \mathrm{~cm}$ can be determined through their velocity in a vessel with a diameter of $3 \mathrm{~cm}$. As a result of using formula (2), all experimental points in Fig. 1,b, taking into account the measurement error of the order of $\pm 3 \%$, are located near one curve.

From the similarity criterion for the diameters of the vessels (2), one can obtain a similar criterion for the diameters of the spheres.

The experimental data shown in Fig. 1, a can be reduced to Fig. 1,b if we use the similarity criterion for the velocity of spheres, based on NF (1).

The similarity of the velocity of spheres follows from the equality of NF for spheres of different diameters. For example, the velocity of spheres with a diameter of $2.5 ; 2 ; 1.5 \mathrm{~cm}$ can be determined by the velocity of the model (sphere with a diameter of $3 \mathrm{~cm}$ ) by:

$$
\mathrm{v}_{x}=\mathrm{v}_{3} \sqrt{\mathrm{d}_{x} / \mathrm{d}_{3}},
$$

where $\mathrm{d}_{x}$ is the diameter of a sphere in a vessel of diameter $1.5 ; 2 ; 2.5 ; 3 \mathrm{~cm}$.

It should be noted that based on the experimental data $[6,8]$, the similarity criterion (3) is applicable for Reynolds numbers $R e$ in the range $2<\log (R e)<4.5$, where $R e=\rho \mathrm{v} d \eta^{-1}$ is the Reynolds number; $\rho$-density of water; $\eta$ - coefficient of dynamic viscosity of water.

The similarity criterion for water (3) is a special case.

In the general case, the experimentally obtained dependence of the logarithm of the resistance coefficient $\log (\psi)$, where $\psi=\frac{4 g\left(\rho_{s}-\rho_{f}\right) \mathrm{d}}{3 \rho_{f} \mathrm{v}^{2}}$, on the logarithm of the Reynolds number $\log (R e)$ is shown in Fig. 2 [9]. Here $\rho_{s}, \rho_{f}$ - density of the sphere material and the liquid are respectively.

In Fig. 2, a lines for different values of the ratio are shown in different colors d/D. Markers in the form of a cross of the same color as the corresponding line, show the points of Fig. 1,a. These points correspond to the velocity of the sphere $115,130,115 \mathrm{~cm} / \mathrm{s}$ for $\mathrm{d} / \mathrm{D}=0.6 ; \mathrm{d} / \mathrm{D}=0.4 ; \mathrm{d} / \mathrm{D}=0.2$ respectively. You can see a good correspond match of the experimental data.

For the general case, the similarity of the process of motion of a sphere under the action of gravity can be shown as follows. 

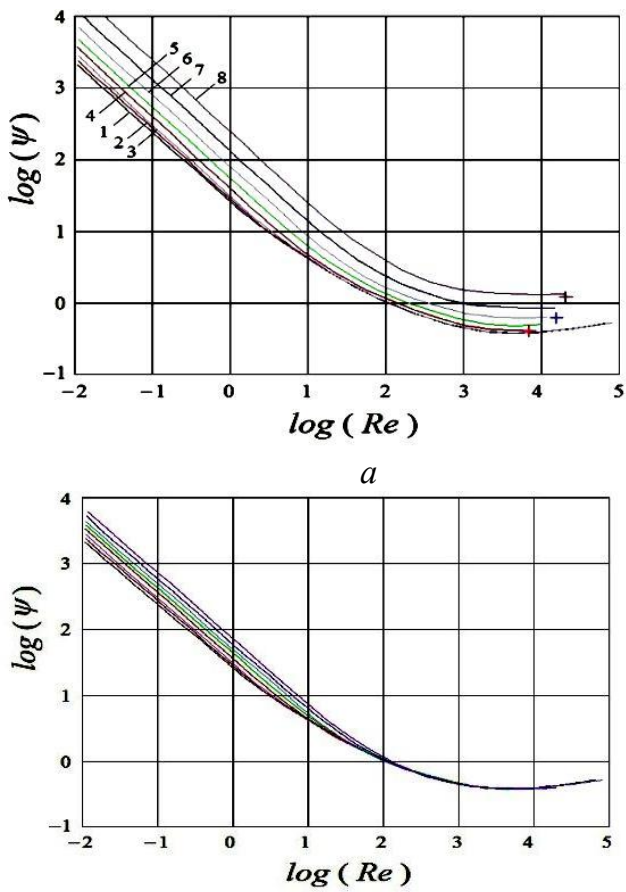

$b$

Fig. 2. Dependence of the logarithm of the resistance coefficient $\log (\psi)$ on the logarithm of the Reynolds number $\log (\operatorname{Re}): 1$ - control line; $2-d / D=0.05$;

$$
\begin{gathered}
3-d / D=0.1 ; 4-d / D=0.2 ; 5-d / D=0.3 ; \\
6-d / D=0.4 ; 7-d / D=0.5 ; 8-d / D=0.6
\end{gathered}
$$

We consider the diameter of the sphere to be constant and equal to D. We also consider the similarity criterion for the Freud number to be fulfilled $\mathrm{v} / \sqrt{\mathrm{D}}=\mathrm{C}=$ const . Then we have:

$$
\begin{aligned}
& \log (\psi)=\log \left(\psi_{D}\right)+\log (\mathrm{d} / \mathrm{D}), \\
& \log (R e)=\log \left(R e_{D}\right)+\log (\mathrm{d} / \mathrm{D}),
\end{aligned}
$$

where

$$
\psi_{D}=\frac{4 g\left(\rho_{s}-\rho_{f}\right) \mathrm{D}}{3 \rho_{f} \mathrm{v}^{2}}, R e_{D}=\frac{\rho_{f} \mathrm{Dv}}{\eta}, R e=R e_{D}(\mathrm{~d} / \mathrm{D}) .
$$

The result obtained allows to expose the curves of Fig. 2, a parallel to the transfer along the ordinate axis by the value $\log (\mathrm{d} / \mathrm{D})$ and leave the curves as is, because the transfer in the direction of the abscissa axis is insignificant, i.e. $\log \left(R e_{D}\right)>>\log (\mathrm{d} / \mathrm{D})$.

As a result of such actions we will receive curve Fig. 2,b.

It follows from the figure that the similarity criterion is satisfied for Reynolds numbers $2<\log (R e)<4.5$. According to this criterion the coordinates $\left(\mathrm{Y}_{0}, \mathrm{X}_{0}\right)$, of the intersection of the line $\log \left(\psi_{D}\right)$ with the line of Fig. 2,b in the interval $2<\log (R e)<4.5$ determine the constant $\mathrm{C}$ and the ratio as follows:

$$
\begin{aligned}
& \log \left(\psi_{D}\right)=\mathrm{Y}_{0}, \\
& \log \left(\operatorname{Re}_{D}\right)+\log (\mathrm{d} / \mathrm{D})=X_{0} .
\end{aligned}
$$

From Figs. 1,b; 2,b it follows that all experimental points, taking into account the error in the range of Reynolds numbers $2<\log (R e)<4.5$ are located near one curve.
Thus, in this section, based on experimental data, the existence of the principle of similarity for the velocity of falling under the force of gravity of spheres in cylindrical vessels filled with water is shown. The principle of similarity is that the ratio of the velocities of the spheres is inversely proportional to the square root of the ratio of the diameters of the spheres. This principle is similar to the well-known similarity criterion for determining the velocity of movement of designed ships based on the results of testing their small-sized models [11].

\section{ANALYTICAL DESCRIPTION OF THE VELOCITY OF INCIDENCE OF SPHERES IN A CYLINDRICAL CHANNEL FILLED WITH A VISCOUS LIQUID}

To construct an analytical dependence of the velocity of incidence of spheres in cylindrical channels filled with viscous liquids on their diameter, we will proceed from experimental data for water. Approximation of points, the location of which is shown in Fig. 1,b, was performed using a polynomial functions of the coordinate. In this case, the section of the curve in the interval $0 \leq \mathrm{v} / \mathrm{v}_{\max }<0.22$ near the origin $(0<x<<1)$ will be considered below, using the formula for the velocity of a sphere in a channel with a large diameter.

For other experimental points, the analytical expression for the velocity of the sphere has the form:

$$
\mathrm{v}(x)=3.29 \cdot \mathrm{v}_{\max } \cdot(1-x)^{1.15}(x-0.01)^{0.65} \text {. }
$$

In Fig. 3 shows the analytical dependence of the velocity of fall of a sphere in a cylindrical channel filled with water, which by means of the similarity criterion (2) summarizes the experimental data given in [9].

From Fig. 3 follows the quantitative correspondence of experimental points and analytical dependence (6). The correspondence of the experimental points and the analytical dependence (6) can be to estimate on the value by calculation of standard deviation and the correlation analysis.

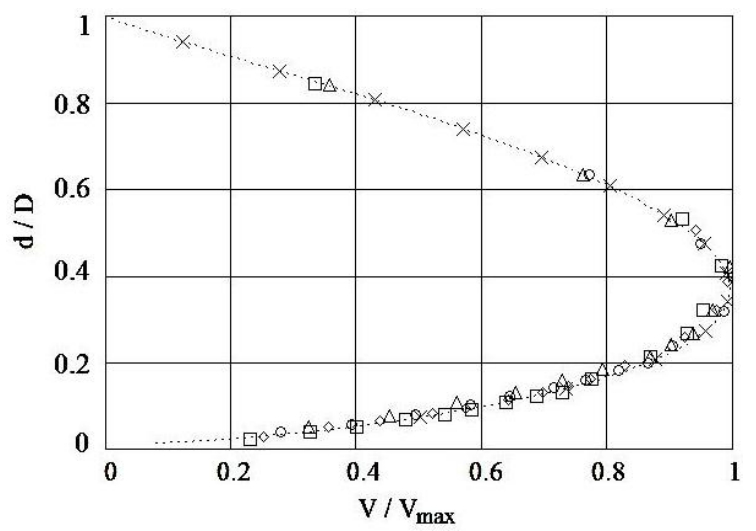

Fig. 3. The analytical dependence of the velocity of spheres in water $v$ on diameter $d / D$ is shown by the marker " $\times$ ". Other markers correspond to the values in Fig. 1

The Table shows the results of statistical analysis of the correspondence of the experimental points and the analytical curve (6). The following notations are used in the table: 
$\Delta \xi=\sqrt{\frac{\sum_{i=0}^{N}\left(\mathrm{v}\left(x_{i}\right) / \mathrm{v}_{\max }-\mathrm{v}_{i} / \mathrm{v}_{\max }\right)^{2}}{N-1}} ; N$ - number of meas-

urements [13]; CCP - the strength of the connection between the analytical $\mathrm{v}\left(x_{i}\right) / \mathrm{v}_{\max }$ experimentally measured $\mathrm{v}_{i} / \mathrm{v}_{\max }$ value of the velocity [14].

Data of statistical analysis of comparison of experimental points and analytical curve (6)

\begin{tabular}{|l|c|c|c|c|}
\hline $\begin{array}{l}\text { Comparison } \\
\text { parameter }\end{array}$ & $\mathrm{d}=3 \mathrm{~cm}$ & $\mathrm{~d}=2.5 \mathrm{~cm}$ & $\mathrm{~d}=2 \mathrm{~cm}$ & $\mathrm{~d}=1.5 \mathrm{~cm}$ \\
\hline $\begin{array}{l}\text { The standard } \\
\text { deviation, } \Delta \xi\end{array}$ & 0.018 & 0.017 & 0.024 & 0.04 \\
\hline $\begin{array}{l}\text { Pierceon corre- } \\
\text { lation coeffi- } \\
\text { cient }(\mathrm{CCP})\end{array}$ & 0.998 & 0.999 & 0.999 & 0.993 \\
\hline
\end{tabular}

As can be seen from the table, the standard deviation $\Delta \xi$ is at the level of $1.7 \ldots 4 \%$. This indicates the validity of the application of the similarity criterion based on the Freud number. In addition, the value of the CCP on the Chaddock scale [13] shows a very high strength of the linear relationship of experimental and theoretically calculated points, because it is close to unity. This conclusion also confirms the legitimacy of the use of the similarity criterion (3).

\section{ASYMPTOTIC DESCRIPTION OF THE VELOCITY OF FALL OF A SPHERE IN A CYLINDRICAL CHANNEL OF ARBITRARY DIAMETER}

With sufficiently large diameters of the cylindrical channel, the velocity of the sphere $\mathrm{v}(d)$ is determined by Stokes' formula [15]:

$$
\mathrm{v}(\mathrm{d})=\frac{2}{9} x^{2} \mathrm{D}^{2} \frac{g\left(\rho_{s}-\rho_{f}\right)}{\eta} .
$$

For the analytical description of the velocity of the sphere in the whole range of changes in the diameter of the channel, we assume that the velocity of the sphere is zero at $x=1$. This follows from simple physical considerations: the velocity of the sphere is zero due to contact with the walls of the channel, which are at rest.

At large channel diameters, when $x<<1$, at a point $x=x_{0}$, the velocity (6) must continuously change to the velocity (7). Therefore, we assume that $x=x_{0}$ expressions (6) and (7) are identically equal.

We also assume that the first derivatives of velocities on the variable $x$ at the point of cross linking $x=x_{0}$ are continuous.

With this method of stitching expressions (6), (7), the diameters of the channel $\mathrm{D}_{0}$ and sphere $x_{0}$ remain undefined.

To determine them in water (in water at $\mathrm{d}=3 \mathrm{~cm}$, the maximum velocity of the sphere is $131 \mathrm{~cm} / \mathrm{s}$ ) it is necessary to solve a system of equations composed of the condition of continuity of functions (6), (7) and their first derivatives at the point $x_{\mathrm{O}}$ :

$$
\begin{aligned}
& x_{0}=\frac{\left(1-x_{0}\right)^{0.575}\left(x_{0}-0.01\right)^{0.325}}{A\left(\mathrm{D}_{0}\right)}, \\
& 2=\left[-\frac{1.15}{\left(1-x_{0}\right)}+\frac{0.65}{\left(x_{0}-0.01\right)}\right] x_{0},
\end{aligned}
$$

where $A\left(\mathrm{D}_{0}\right)=\mathrm{D}_{0} \sqrt{\frac{2 \cdot g \cdot\left(\rho_{\mathrm{d}}-\rho_{\mathrm{f}}\right)}{9 \cdot 3.29 \cdot \eta \cdot \mathrm{v}_{\text {max }}}}=185.472 \cdot \mathrm{D}_{0}$.

Equation (9) is solved analytically. From its two solutions, the one that satisfies the condition $x_{0}<<1$ ischosen.

The diameter of the channel is determined from equation (8), using the values of the parameters: $\rho_{s}=7800 \mathrm{~kg} / \mathrm{m}^{3}, \rho_{f}=1000 \mathrm{~kg} / \mathrm{m}^{3}, \eta_{\text {water }}=10^{-3} \mathrm{~kg} /(\mathrm{m} \cdot \mathrm{s})$ $[7,9]$.

In (8), (9) the density of steel is used, since experiments investigated the free fall of steel balls in water. Since a structural material based on graphite is used in the HTGR core, the density of SFE should be used in (8), (9).

As a result of solving the system of equations (8), (9) we obtain the value of the ratio of the diameter of the sphere to the diameter of the cylindrical channel and the diameter of the cylindrical channel, respectively:m.

In Fig. 4 shows the analytically obtained from (8), (9) the dependence of the velocity of a sphere falling in a cylindrical channel with water.

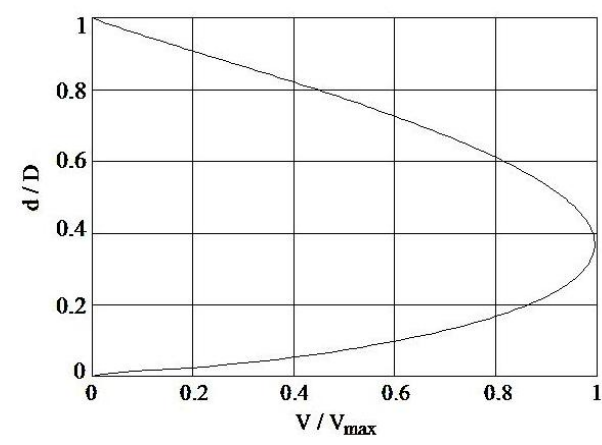

Fig. 4. Analytical dependence of the velocity of falling of a sphere in water $v / v_{\max }$ on its diameter $d / D$ for the entire range of changes in the ratio of the diameter of the sphere to the diameter of the channel $((0 \leq d / D \leq 1)$

From the study it can be concluded that the diameter of the sphere $x_{0}$ at which the cross linking of expressions (6), (7) is a small value 0.015 of the diameter of the channel. From (8) it follows that the diameter of the sphere increases in proportion to the square root of the dynamic viscosity of the liquid.

Thus, knowing the dependence of the velocity of fall of the model sphere in a cylindrical channel with water from the ratio of the diameter of the sphere to the diameter of the channel, we can determine the velocity of fall of a sphere of arbitrary diameter in water depending on the ratio of sphere diameter to channel diameter. To do this, in Fig. 4 should be replaced $v_{\max }$ by $v_{\max }^{\prime}=v_{\max } \sqrt{3 / d^{\prime}}$, where $\mathrm{d}^{\prime}$ is the diameter of the investigated sphere, and, in particular, the diameter of SFE $6 \mathrm{~cm}$. 


\section{CONCLUSIONS}

The design and implementation of HTGR with a channel core based on SFE poses the task of accurately estimating the velocity of free fall of SFE in cylindrical channels with a viscous liquid. In addition, determining the dependence of the velocity of free fall of spherical bodies in cylindrical channels with a viscous fluid is not only scientific but also of practical interest for solving problems of viscometry, medicine.

To solve this problem, the known experimental data are generalized, and a criterion of similarity for the velocity of free fall of spheres in cylindrical channels with water is found. In the range of Reynolds numbers $2<\log (\operatorname{Re})<4.5$, the similarity criterion is formulated on the basis of the Freud number. It is that the ratio of the velocity of the spheres is proportional to the root of the quadratic ratio of their diameters. The obtained criterion corresponds to the known similarity criterion for modeling the movement of ships, as well as in their model tests.

By the method of stitching the analytical dependence of the velocity of the sphere in water taking into account the walls of the channel with the expression defining the motion of the sphere in the channel of infinite diameter, the analytical dependence of the velocity of the sphere in water for the whole range of sphere diameter $(0 \leq \mathrm{d} / \mathrm{D} \leq 1)$.

It is shown that in water the diameter of the sphere at which the velocity of the sphere moving in the channel changes to the velocity where the influence of the channel walls is insignificant is a small value of 0.015 from the diameter of the channel. In this case, the diameter of the channel increases in proportion to the square root of the dynamic viscosity of the liquid.

It is concluded that from the dependence of the velocity of fall of the model sphere in a cylindrical vessel with water on the dimensionless diameter of the sphere, it is possible to determine the velocity of fall of the sphere in water of arbitrary diameter.

The obtained similarity criterion and the analytical dependence of the velocity of the sphere in water for the entire range of changes in the diameter of the sphere and the channel can be used to estimate the velocity of free fall of SFE in cylindrical HTGR channels.

\section{REFERENCES}

1. V.H. Grebennik, N.E. Kuharkin, H.H. Ponomarev-Stepnoj. Vysokotemperaturnye gazoohlazhdaemye reaktory - innovatsionnoe napravlenie razvitija atomnoj energetiki. M.: "Energoatomizdat", 2008, 136 s. (in Russian).
2. A.G. Samojlov, V.S. Volkov, M.I. Solonin. Teplovydelyayushchie elementy yadernyh reaktorov: Ucheb. posobie dlya vuzov. M.: "Energoatomizdat", 1996, 400 s. (in Russian).

3. V.F. Zelenskij, N.P. Odejchuk, V.K. Yakovlev, V.A. Gurin. Modern Status of Works on HighTemperature Gas-Cooled Reactors (HTGR) in the World and Prospects of their Application in Ukraine // PAST. Series "Physics of Radiation Effect and Radiation Materials Science” (94). 2009, N 4-2, p. 247-255.

4. Advances in Small Modular Reactor Technology Developments. A Supplement to: IAEA Advanced Reactors Information System (ARIS), 2018, Edition; http://aris.iaea.org

5. Hoai Nam Tran, Van Khanh Hoang. Core Characteristics of an OTTO Refueling Pebble Bed Reactor and Comparison with a Multi-Pass Scheme // Proceedings of the HTR 2012 Tokyo, Japan, October $28-$ November 1. 2012, Paper HTR2012-5-025.

6. V.P. Smetannikov, I.X. Ganev, V.D. Kolganov i dr. Proektirovanie energeticheskih ustanovok s vysokotemperaturnymi gazoohlazhdaemymi reaktorami / Pod red. chl.-kor. AN SSSR I.Ya. Emel'yanova. M.: "Energoizdat", 1981, 232 s. (in Russian).

7. L.D. Landau, E.M. Lifshic. Teoreticheskaya fizika. Gidrodinamika. T. 6. M.: "Nauka, Gl. red. fiz.-mat. lit.", 1986, 736 s. (in Russian).

8. R.L. Whitmore The sedimentation of suspensions of spheres // Br. J. Appl. Phys. 1955, v. 6, N 7, p. 239245 .

9. V. Fidleris, R.L. Whitmore. Experimental determination of the wall effect for spheres falling axially in cylindrical vessels // Br. J. Appl. Phys. 1961, v. 12, N 9, p. 490-494.

10. R. Di Felice. A relationship for the wall effect on the settling velocity of a sphere at any flow regime // International Journal of Multiphase Flow. 1996, v. 22, issue 3, p. 527-533.

11. A.M. Prohorov, D.M. Alekseev, A.M. Baldin, A.M. Bonch-Bruevich, A.S. Borovik-Romanov i dr. Fizicheskaya enciklopediya. T. 5. M., 1998, 692 s. (in Russian).

12. N.F. Emel'yanov. Hodkost' vodoizmeshchayushchih morskih sudov: Uch. pos. Vladivostok: "Dal'rybvtuz", 2004, 249 s. (in Russian).

13. G. Shilling. Statisticheskaya fizika v primerah. M.: "Mir", 1976, 432 s. (in Russian).

14. I.I. Eliseeva. Ekonometrika: Uchebnik. M.: "Finansy i statistika", 2007, 576 s. (in Russian).

15. G. Lamb. Gidrodinamika. M.: OGIZ, 1947, 929 s. (in Russian).

Article received 21.05.2021

\section{КРИТЕРИЙ ПОДОБИЯ ДЛЯ СКОРОСТИ СВОБОДНОГО ПАДЕНИЯ ШАРОВЫХ ТВЭЛОВ В ЦИЛИНДРИЧЕСКИХ КАНАЛАХ С ВЯЗКОЙ ЖИДКОСТЬЮ}

\section{О.Л. Андреева, Л.А. Булавин, В.И. Ткаченко}

Внедрение атомных высокотемпературных газоохлаждаемых реакторов (ВТГР) с канальной активной зоной на основе шаровых твэлов (ШТ) ставит задачу по определению скорости их свободного падения в цилиндрических каналах с вязкой жидкостью. Для ее решения обобщены экспериментальные данные других 
исследователей, и для определенного диапазона изменения числа Рейнольдса найден критерий подобия для скорости свободного падения сфер в цилиндрических каналах с водой. Сделан вывод о том, что из зависимости скорости падения модельной сферы в цилиндрическом канале с водой от соотношения диаметра сферы с диаметром канала можно определить зависимость скорости падения в воде сферы произвольного радиуса от соотношения ее диаметра к диаметру канала.

\section{КРИТЕРІЙ ПОДІБНОСТІ ДЛЯ ШВИДКОСТІ ВІЛЬНОГО ПАДІННЯ КУЛЬОВИХ ТВЕЛІВ У ЦИЛІНДРИЧНИХ КАНАЛАХ ІЗ В'ЯЗКОЮ РІДИНОЮ}

\section{О.Л. Андреєва, Л.А. Булавін, В.І. Ткаченко}

Впровадження атомних високотемпературних газоохолоджуваних реакторів (ВТГР) з активною канальною зоною на основі кульових твелів (КТ) ставить задачу з визначення швидкості їх вільного падіння в циліндричних каналах з в'язкою рідиною. Для ії рішення узагальнені експериментальні дані інших дослідників, і для певного діапазону значень числа Рейнольдса знайдено критерій подібності для швидкості вільного падіння сфер у циліндричних каналах з водою. Зроблено висновок про те, що із залежності швидкості падіння модельної сфери в циліндричному каналі з водою від співвідношення діаметра сфери до діаметра каналу можна визначити залежність швидкості падіння у воді сфери довільного радіуса від співвідношення ії діаметра до діаметра каналу. 